\title{
Dialogic Reading Sebagai Upaya Mengembangkan Keterampilan Berbahasa Anak Usia Dini
}

\author{
Vina Anggia Nastitie Ariawan', Inne Marthyane Pratiwi ${ }^{2}$ \\ 'STKIP Majenang \\ ${ }^{2}$ Fakultas Tarbiyah dan Keguruan UIN Sunan Gunung Djati Bandung \\ Email: vivianatsir@gmail.com ${ }^{1}$, inne.mp@uinsgd.ac.id²
}

\begin{abstract}
Abstrak
Keterampilan berbahasa merupakan keterampilan dasar yang dikuasai serta dipelajari anak usia dini. Keterampilan berbahasa diperoleh anak melalui interaksi dengan orang tua. Periode perkembangan bahasa anak usia dini dikategorikan menjadi dua yaitu periode pralinguistik dan linguistik. Periode pralinguistik dilalui anak ketika bayi. Apabila pada periode pralinguistik anak dikenalkan dengan penggunaan bahasa yang tepat maka keterampilan berbahasa anak berkembang di periode linguistik. Intensitas suatu interaksi akan berpengaruh pada keterampilan menyimak dan berbicara anak usia dini. Oleh sebab itu, orangtua serta guru selaku sosok yang dekat dengan anak sangat perlu memfasilitasi perkembangan bahasa anak. Dialogic reading merupakan pendekatan yang digunakan untuk mengembangkan keterampilan berbahasa serta literasi dasar anak. Dialogic reading memberi banyak kesempatan pada anak untuk berbicara sehingga keterampilan berbahasa serta rasa percaya dirinya semakin berkembang.
\end{abstract}

Kata kunci: anak usia dini, bahasa, dialogic reading

\begin{abstract}
Language skills are basic skills that are mastered and learned early childhood. Language skills obtained by the child through interaction with parents. Early childhood language development periods are categorized into two, namely pre-linguistic and linguistic periods. Pre-linguistic periods are passed by the child as a baby. If in the pre-linguistic period the child is introduced to the proper use of language then the language skills of the child develop in the linguistic period. The intensity of an interaction will affect the skills of listening and speaking of early childhood. Therefore, parents and teachers as a close to the child are very necessary to facilitate the development of the language of children. Dialogic reading is an approach used to develop language skills and basic literacy of children. Dialogic reading provides many opportunities for children to speak so that language skills and self-confidence are growing.
\end{abstract}

Keywords: dialogic reading, early childhood, language 


\section{Pendahuluan}

Salah satu bagian penting dari perkembangan anak yaitu perkembangan berbahasa. Bahasa merupakan sarana anak untuk belajar, berkomunikasi, dan berinteraksi dengan teman sebaya sehingga anak dapat mengenal dunia luar (Brock \& Rankin, 2008). Interaksi merupakan aktivitas yang penting bagi anak usia dini karena berdampak pada kelancaran berbicara serta membangun kepercayaan dirinya. Interaksi tercipta dari lingkungan yang terdekat dengan anak yaitu keluarga kemudian semakin berkembang di lingkungan sekolah. Apabila sejak usia dini anak terlatih untuk berinteraksi maka berpengaruh pada perkembangan berbahasa serta literasi awal (Simsek \& Erdogan, 2015).

Anak mengenal bahasa sejak ia mulai bisa mendengar. Hal ini terbukti ketika anak merespons setiap ucapan melalui tangisan, senyum, tatapan, atau gerakan. Oleh karena itu, sejak anak berada dalam masa awal kehidupan orang tua dianjurkan untuk berinteraksi menggunakan bahasa yang sesuai kaidah meskipun bahasa yang digunakan berupa bahasa ibu (Hindman, Skibbe, \& Foster, 2013). Penggunaan bahasa yang benar bertujuan untuk menghindari adanya kesalahan atau kesulitan dalam pemerolehan bahasa. Anak merekam semua percakapan yang ditujukan pada dirinya sehingga ketika mulai berbicara ia akan mengucapkan kosakata yang pernah terekam. Penggunaan bahasa yang kurang tepat tentunya akan berdampak pada pemerolehan bahasa anak (Owens, 2012). Sebagai contoh, orang tua menyebut susu dengan cucu, takut dengan atut, atau piring dengan piling. Kosakata yang salah pelafalannya berakibat pada fonologi anak serta keterampilan berbahasa lainnya seperti membaca (Elmonayer, 2013).

Keterampilan berbahasa yang pertama dikenalkan pada anak yaitu keterampilan berbicara. Anak yang terlatih berbicara sejak usia dini akan lebih mudah menguasai keterampilan membaca. Keterampilan berbicara yang diajarkan sejak dini juga menghindari adanya kesulitan dalam membaca. Selain itu, keterampilan berbicara berkaitan erat dengan keterampilan menyimak karena kelancaran berbicara dipengaruhi oleh daya simak (Hipfner-Boucher, dkk., 2014). Pembelajaran berbahasa anak usia dini terintegrasi dengan muatan pembelajaran lain. Sebagai upaya mengembangkan keterampilan berbahasa anak, guru perlu memberikan pengalaman berbahasa melalui percakapan ringan yang biasa digunakan dalam kehidupan sehari-hari (Lonigana, dkk., 2013). Percakapan yang sering dibangun guru di sekolah dapat membangun keterampilan dasar berbahasa serta literasi dasar anak usia dini (Assel, Landry, Swank, 
\& Gunnewig, 2007. Semakin meningkatnya atmosfer percakapan maka guru perlu mentransfer pengetahuan baru sehingga pengetahuan anak bertambah. Dialogic reading dapat menjadi salah satu upaya guru untuk mengembangkan keterampilan berbahasa. Dialogic reading adalah pendekatan pembelajaran membaca dengan bantuan bahan ajar untuk mengembangkan dan meningkatkan keterampilan berbahasa serta literasi dasar (Lever \& Senechal, 2011).

\section{Pembahasan}

\section{Perkembangan Bahasa Anak}

Menurut Levin (dalam Zubaidah, 2004) pada masa perkembangan sistem bunyi (fonologis) anak memiliki keutuhan dalam bersuara; pada masa perkembangan sintaksisnya (sistem gramatikal) anak telah mampu memproduksi suara; pada masa perkembangan sistem maknanya (semantik) anak telah memiliki keutuhan untuk memberikan makna; dan pada masa perkembangan sistem sosial bahasanya (pragmalik) anak telah mampu menerapkan ucapan dalam kehidupan sosial secara utuh. Di sisi lain, Dworetzsky (1990 dalam Zubaidah, 2004) menyatakan bahwa dalam kehidupan manusia mengalami perkembangan bahasa melalui dua tahapan, yakni pralinguistik dan linguistik.

\section{Periode Pralinguistik}

Periode pralinguistik adalah masa anak sebelum mengenal bahasa atau belum mampu berbahasa. Saat bayi mulai tumbuh, secara berangsur-angsur ia mengembangkan bahasanya melalui urutan tahap demi tahap. Tahap pertama, sejak lahir sampai sekitar usia 2 bulan yaitu masa fonasi (phonation stage). Pada masa ini bayi sering membuat bunyi-bunyi yang menyenangkan atau quasi vowel. Disebut quasi karena pelafalan tidak sepenuh dan sekaya suara vokal yang dibuat sebenarnya. Kuasi vokal dibentuk dari suara yang mirip bahasa pertama. Selanjutnya bayi berada dalam masa going stage antara usia 2 dan 4 bulan, yaitu bayi mengucapkan kata sejenis kombinasi quasi vokal dengan keras, sebagai tanda awal konsonan. Kemudian, pada rentang usia 4 sampai 7 bulan anak memproduksi beberapa kata baru atau disebut masa expansion stage.

Tahap kedua, setelah anak belajar mengeluarkan suara dalam bentuk tangis lalu anak mulai mengoceh. Bunyi yang muncul pada masa ini, yakni antara 7 sampai 10 bulan, berupa bunyi yang dapat dipisahkan antara vokal dan konsonannyatetapi belum ada bunyi yang membedakan makna. Masa ini disebut juga sebagai tahap konikal (cononical stage), bayi semakin berkembang kemampuan mengocehnya karena mulai 
menghasilkan suku kata dan menirukan ucapan seperti bababa atau mamama. Pada tahap konikal, orang tua dapat mengidentifikasi kemampuan pendengaran bayi. Hal yang menarik untuk dipelajari pada tahap ini yaitu apabila bayi mulai mengoceh beberapa suku kata maka bayi dapat dikatakan memiliki pendengaran yang baik. Sementara itu, apabila bayi sudah memasuki masa mengoceh tetapi tidak mengeluarkan ocehan maka indera pendengaran bayi perlu diperiksakan.

Tahap ketiga, setelah melalui masakononikal secara meningkat bayi mempersempit penggunaan fonem mereka, terutama pada fonem yang akan mereka gunakan dalam bahasa yang mereka pelajari. Tahap ini disebut dengan tahap kontraksi (contraction stage) dan umumnya terjadi antara usia 10 sampai 14 bulan. Pada masa ini bayi akan memperoleh langkah dan irama bahasa serta belajar meniru hal yang mereka dengar. Jalongo (1992 dalam Zubaidah, 2004) mengelompokkan perkembangan bahasa anak tahap pralinguastik sejak bayi lahir sampai usia 11 bulan. Pada tahap perkembangan bahasa ini, anak tampak masih dalam taraf berlatih mengenal lingkungannya sendiri atas dasar yang dirasakan, dilihat, dan didengarnya. Ketika anak merasakan sesuatu tetapi belum mampu mengucapkannya, ia hanya mampu memberikan tanda bahwa dia senang atau tidak senang. Ungkapan rasa tidak senang ditunjukkan dengan menangis atau menunjukkan kegelisahannya. Ketika anak senang dia mampu menunjukkan kesenangannya melalui perilaku yang tidak rewel, melakukan gerakan positif, dan selalu memberikan respons ketika diajak berkomunikasi.

2. Periode Linguistik

Kata infant berasal dari kata latin yang bermakna tanpa ucapan atau tidak berbicara. Anak dikategorikan sebagai infant ketika memasuki usia 14 bulan. Pada masa tersebut, anak mulai tampak perkembangan bahasanya karena ia sudah mulai mampu menggunakan kata-kata dalam berbicara. Kata yang dimaksud adalah ucapan yang berhubungan langsung dengan benda atau kegiatan tertentu, sebagai bentuk dasar. Misalnya mama, papa, baba, dan baru kemudian mempelajari kata abstrak. Anak telah mampu menggunakan kata benda yang luas serta telah mampu menggunakan kosakata yang terdiri antara 3 sampai dengan 50 kata (Zubaidah, 2004).

Anak sudah mampu menerima bahasa dengan menggunakan bahasa telegrafik 2-3 kata. Selanjutnya, anak mampu berkomunikasi dengan menggunakan kata antara 3-50 kata. Anak ketika berusia sekitar 3 tahun, kosakatanya bertambah setiap hari. Pada usia tersebut, anak memiliki kosakata antara 200 sampai 300 kata. Kemudian, saat usia 4 tahun anak telah mampu menerapkan pengucapan dan tata bahasa. Anak telah memiliki kosakata sebanyak 1400 sampai 1600 kata. Pada usia 5 sampai 6 tahun, anak 
telah memiliki susunan kalimat dan tata bahasa yang benar, baik dalam penggunaan awalan maupun kata kerja. Panjang kalimat yang diucapkan rata-rata setengah baris per kalimat, kemudian meningkat menjadi 6-8 kata. Anak mampu menggunakan kosakata kira-kira 2500 kata dan mengerti sekitar 6000 kata (Zubaidah, 2004).

Perkembangan berbahasa anak usia dini di sekolah lebih ditujukan pada (a) kesanggupan menyampaikan pikiran kepada orang lain, (b) mengembangkan perbendaharaan kala, (c) menangkap pembicaraan orang lain, (d) keberanian untuk mengemukakan pendapat. Guru hendaklah pandai memilih pendekatan pembelajaran yang relevan dengan kebutuhan anak sehingga ia dapat mencapai perkembangan bahasa yang sesuai dengan usianya.

\section{Dialogic Reading terhadap Keterampilan Berbahasa Anak Usia Dini}

Dialogic reading adalah praktik pembelajaran membaca dengan bantuan bahan ajar untuk mengembangkan dan meningkatkan keterampilan berbahasa serta literasi dasar (Lever \& Senechal, 2011). Dialogic reading bertujuan untuk mengidentifikasi fonologi anak usia dini. Ketika guru berbincang dengan anak, tugas yang perlu dilakukan yaitu mengidentifikasi ketepatan serta kejelasan kata yang mereka lafalkan (Gupta \& Lee, 2015). Kemudian, jika anak kurang tepat atau kurang jelas melafalkan kata maka guru perlu memberi contoh pelafalan yang tepat dan jelas pada anak. Selanjutnya, anak diminta mengulang kata tersebut hingga pelafalannya tepat dan jelas. Dialogic reading bermanfaat untuk meningkatkan keterampilan berbicara anak, menambah pengetahuan akan kosakata baru, serta perkembangan morfologi (Fleury \& Schwartz, 2017 hlm. 20). Guru memiliki peran sentral dalam dialogic reading karena ia aktivitas membaca dilakukan melalui suatu percakapan. Strategi yang dapat digunakan dalam pendekatan dialogic reading meliputi picture description, talk a mile a minute, dan puppets role play (Gupta \& Lee, 2015).

Strategi picture description memberi kesempatan pada anak untuk berbicara tanpa memerhatikan sintaks, tata bahasa, atau aturan berbahasa lainnya. Strategi picture description membangun anak untuk berinteraksi dalam suatu kelompok kecil (Ruston \& Schwanenflugel, 2010). Interaksi yang terbangun dalam kelompok kecil akan melatih anak untuk berbicara di lingkup yang lebih luas seperti di depan kelas atau di suatu pertunjukkan. Strategi ini memerlukan gambar sebagai sarana untuk berinteraksi. Sebagai contoh, guru menunjukkan gambar kelinci lalu meminta anak untuk menyebutkan nama binatang yang ada dalam gambar. Kemudian, guru memberi pertanyaan lanjutan seperti nama bagian tubuh binatang. Ketika kegiatan ini berlangsung, guru perlu memerhatikan pelafalan anak saat menyebutkan kosakata. 
Apabila ada anak yang salah melafalkan maka guru bertugas mengajarkan anak untuk melafalkan kosakata yang tepat. Setelah anak menyebutkan beberapa contoh gambar, guru dapat meminta anak untuk bercerita tentang hal-hal yang disukai anak. Langkah terakhir, guru dapat menambahkan pengetahuan baru tentang sesuatu hal yang mungkin belum diketahui anak.

Anak memerlukan stimulasi dalam pengembangan kosakata yang bermanfaat untuk meningkatkan keterampilan berbicara. Strategi talk a mile a minute dapat menjadi salah satu cara untuk mengembangkan keterampilan berbahasa anak. Strategi ini melatih anak untuk bercerita sesuai dengan tema yang ditentukan guru. Strategi ini juga bermanfaat sebagai sarana melatih konsentrasi serta pemahaman anak (Gupta \& Lee, 2015). Hal ini dikarenakan anak harus bercerita sesuai dengan tema yang telah dipilih guru. Tema yang diajukan tentunya disesuaikan dengan lingkungan internal dan eksternal anak sehingga anak tidak terbebani. Penentuan tema juga dapat dilakukan oleh anak agar ia lebih bebas bercerita. Strategi ini dapat diaplikasikan dengan cara menceritakan kembali. Guru sebelumnya menceritakan suatu kisah lalu dilanjutkan dengan memberi kesempatan bercerita ulang. Meskipun anak tidak dapat bercerita secara runtut atau ragu-ragu guru perlu memberi apresiasi atas kepercayaan diri anak.

Selain ke dua strategi yang telah dijelaskan, guru dapat mengunakan strategi puppet role play untuk mendukung perkembangan keterampilan berbahasa anak. Melalui puppet role play anak menggunakan puppet sebagai sarana bercerita dengan banyak percakapan. Rief and Heimburge (2007) meyakini bahwa anak yang diberi kesempatan untuk bercerita menggunakan puppet akan meningkatkan rasa percaya diri dan kelancaran berbicara. Melalui puppet anak secara natural akan berimajinasi dan mulai menceritakan imajinasinya. Oleh sebab itu, pada masa usia dini sering sekali dijumpai anak-anak yang bermain peran dalam kegiatan bermain. Anak-anak senang berperan sebagai ayah, sebagai ibu, atau sebagai tokoh kartun yang mereka gemari. Puppet berperan sebagai media visual yang memfasilitasi anak untuk menentukan tema cerita sehingga dapat mengasah kreativitas. Pengenalan puppet diawali dengan cara guru mencontohkan percakapan menggunakan puppet. Kemudian meminta anak untuk menceritakan ulang dengan puppet. Setelahnya, guru dapat membebaskan anak untuk memilih puppet sehingga mereka bebas untuk bercerita (Johnson, 2009). Puppet yang digunakan akan lebih baik jika berkaitan dengan tokoh yang pernah anak jumpai seperti polisi, dokter, petani, atau tukang pos.

Guru perlu untuk menyiapkan suatu percakapan ringan tetapi mengasyikkan sehingga keterampilan berbahasa anak dapat berkembang. Hal yang perlu diingat 
adalah panjang suatu cerita maupun percakapan bukan menjadi ukuran keberhasilan dalam keterampilan berbahasa (Towson, 2015). Apabila guru mampu menghidupkan suasana pembelajaran maka anak akan sangat antusias mengikuti arah percakapan. Anak tidak merasa terbebani dan tanpa sadar ia mampu bercerita sesuai pemahamannya atau ditambah dengan imajinasinya. Dialogic reading membantu anak untuk menjadi pendengar yang aktif sehingga ia lebih senang untuk bercerita daripada hanya diam mendengarkan (Towson, dkk., 2017 hlm. 1).

\section{Simpulan}

Anak usia dini memasuki periode linguistik yang artinya mereka sudah mampu menggunakan kosakata kira-kira 2500 kata dan mengerti sekitar 6000 kata serta mampu berinteraksi dengan kalimat yang utuh. Keterampilan berbicara yang diajarkan sejak dini untuk menghindari adanya kesulitan dalam membaca. Selain itu, keterampilan berbicara berkaitan erat dengan keterampilan menyimak karena kelancaran berbicara dipengaruhi oleh daya simak. Dialogic reading dapat menjadi salah satu upaya guru untuk mengembangkan keterampilan berbahasa. Dialogic reading adalah pendekatan pembelajaran membaca dengan bantuan bahan ajar untuk mengembangkan dan meningkatkan keterampilan berbahasa serta literasi dasar. Strategi yang dapat digunakan dalam pendekatan dialogic reading meliputi picture description, talk a mile a minute, dan puppets role play.

\section{Daftar Pustaka}

Assel, M. A., Landry, S. H., Swank, P. R., \& Gunnewig, S. (2007). An evaluation of curriculum, setting, and mentoring on the performance of children enrolled in prekindergarten. Reading and Writing, 20, hlm.463-494.

Brock, A. \& Rankin, C. (2008). Communication, language and literacy from birth to five. London: Sage.

Elmonayer, R.A. (2013). Promoting phonological awareness skills of Egyptian kindergarteners through dialogic reading. Early Child Development and Care, 183 (9), hlm. 1229-1241.

Fleury, V. P., \& Schwartz, I. S. (2017). A modified dialogic reading intervention for preschool children with autism spectrum disorder. Topics in Early Childhood Special Education, 37, hlm. 16-28.

Gupta, A., \& Lee, G.L. (2015). Dialogic teaching approach with english language learners to enhance oral language skills in the content areas. International Journal of Language and Linguistics, 2 (5), hlm. 
Hindman, A. H., Skibbe, L. E., \& Foster, T. F. (2014). Exploring the nature of parental talk during shared book reading and its contributions to preschool language and literacy: Evidence from the Early Childhood Longitudinal Study-Birth Cohort. Reading \& Writing: An Interdisciplinary Journal, 27, hlm.287-313.

Hipfner-Boucher, K., dkk. (2014). Relationships between preschoolers' oral language and phonological awareness. First Language, 34(2), hlm.178-197.

Johnson, A. P. (2009). Making connections in elementary and middle school social studies. SAGE.

Lever, R., \& Sénéchal, M. (2011). Discussing stories: How a dialogic reading intervention improves kindergarteners' oral narrative construction. Journal of Experimental Child Psychology, 108, hlm.1-24.

Lonigana Ch. J., dkk. (2013). Evaluating the components of an emergent literacy intervention for preschool children at risk for reading difficulties. Journal of Experimental Child Psychology, 114, hlm.111-130.

Owens, R. E. (2012). Language development: An introduction (8th ed.). Upper Saddle River, NJ: Allyn \& Bacon.

Rief, S. F., \& Heimburge, J. A. (2007). How to reach and teach all children through balanced literacy. John Wiley \& Sons.

Ruston, H.P. \& Schwanenflugel, P.J. 2010. Effects of conversation intervention on the expressive vocabulary development of prekindergarten children. Lang Speech Hear Serv Sch, 41 (3), hlm.303-13.

Simsek, Z.C., \& Erdogan, N.I. (2015). Effects of the dialogic and traditional reading techniques on children's language development. Social and Behavioral Sciences, 197, hlm. 754-758.

Towson, J.A. (2015). Dialogic reading: Language and preliteracy outcomes for young children with disabilities. Dissertation, Georgia State University.

Towson, J.A, dkk. (2017). Dialogic reading in early childhood settings: A summary of the evidence base. Topics in Early Childhood Special Education, hlm 1-15.

Zubaidah, E. (2004). Perkembangan bahasa anak usia.dini dan teknik pengembangannya di sekolah. Cakrawala Pendidikan, XXIII (3), hlm. 459-479. 